\title{
Nuclear Factor of Activated T-Cells, Cytoplasmic 2
}

National Cancer Institute

\section{Source}

National Cancer Institute. Nuclear Factor of Activated T-Cells, Cytoplasmic 2. NCI

Thesaurus. Code C93140.

Nuclear factor of activated T-cells, cytoplasmic 2 (925 aa, $\sim 100 \mathrm{kDa}$ ) is encoded by the human NFATC2 gene. This protein is involved in the regulation of cytokine gene expression. 